\title{
Peningkatan Pengetahuan Ibu Hamil dan Calon Ibu tentang Polutan Logam Berat dalam Rangka Pencegahan Cacat Lahir di Rawamangun
}

\author{
Yulia Irnidayanti \\ Reni Indrayanti \\ Biologi, Fakultas Matematika dan Ilmu Pengetahuan Alam, Universitas Negeri Jakarta, \\ Jl. Rawamangun Muka, Jakarta Timur, DKI Jakarta \\ Email: yirnidayanti@unj.ac.id \\ DOI : 10.32672/btm.v2i1.2088
}

\begin{abstract}
ABSTRAK
Data laporan Riskesdas tahun 2007 menyatakan bahwa sebesar 1,4\% bayi baru lahir usia 0-6 hari pertama kelahiran dan 18,1\% bayi baru lahir usia 7-28 hari meninggal disebabkan karena kelainan bawaan. Data WHO SEARO tahun 2010 memperkirakan prevalensi kelainan bawaan di Indonesia adalah 59.3 per 1000 kelahiran hidup. Jika setiap tahun lahir 5 juta bayi di Indonesia, maka akan ada sekitar 295.000 kasus kelainan bawaan pertahun. Mengingat pengetahuan tentang cacat bayi di Indonesia masih awam dikalangan masyarakat Indonesia, kami sebagai dosen akan mendukung program pemerintah melalui pemberian pengetahuan tentang Cegah Bayi Lahir Cacat melalui penerapan pola hidup sehat sebelum dan selama Kehamilan. Maksud dan tujuan kegiatan pengabdian kepada masyarakat berupa penyuluhan, pemeriksaan kadar gula darah, asam urat dan kandungan logam berat. Kegiatan ini diharapkan mampu meningkatkan pengetahuan dan keterampilan orang tua terutama para orang tua, ibu hamil dan calon ibu, kader kesehatan, bagi warga kelurahan Rawamangun, Kecamatan Pulogadung, Kotamadya Jakarta Timur, Provinsi DKI Jakarta. Hasil penyuluhan dan pemeriksaan yang telah dilakukan, 25 warga rawamangun memiliki kondisi asam urat yang normal, namun terdapat tiga warga yang memiliki kadar gula darah tinggi. Kondisi gula darah ibu yang tinggi dan kurang terkontrol dapat menyebabkan keguguran, proses kelahiran biasanya sulit karena ukuran si bayi besar. Hal ini dapat meningkatkan risiko cedera pleksus brakialis dan trauma lainnya selama melahirkan. Hal ini menungkinkan peningkatan risiko cacat saat lahir. Kurangnya pengetahuan bukanlah menjadi satu-satunya penyebab gagalnya suatu usaha pencegahan munculnya kelainan perkembangan janin. Bahan pencemar serta dampaknya merupakan salah satu faktor yang juga dapat mempengaruhi perkembangan janin dan ibu hamil dan calon ibu serta remaja putri.
\end{abstract}

Kata kunci: Timbal, Rambut, Spektrofotometri Serapan Atom

\section{PENDAHULUAN}

Berkembangnya teknologi dan pembangunan yang pesat akan meningkatkan kualitas hidup masyarakat. Akan tetapi perkembangan yang pesat di daerah tersebut 
tentunya juga akan berdampak pada lingkungan sekitar tempat tinggal. Dampak negatif tersebut antara lain penurunan kesehatan akibat pencemaran. Pencemaran yang sangat parah di lingkungan perkotaan adalah pecemaran udara yang berasal dari gas kendaraan bermotor. Ditambah lagi dengan lingkungan tempat tinggal yang padat, dengan letak sumber air yang berdekatan dengan pembuangan limbah rumah tangga, dll.

Salah satu pencemaran pada lingkungan air, udara, dan tanah adalah logam berat. Beberapa logam berat yang berbahaya antara lain merkuri $(\mathrm{Hg})$, timbal $(\mathrm{Pb})$,tembaga $(\mathrm{Cu})$, arsen $(\mathrm{As})$, Besi $(\mathrm{Fe})$ dan kadmium $(\mathrm{Cd})$. Logam berat masuk ke dalam tubuh melalui beberapa jalur, diantaranya melalui makanan yang dikonsumsi baik, polusi udara yang berasal dari asap kendaraan bermotor dan asap pabrik, kosmetik, dan lain-lain (Marganof,2003). Selain asap kendaraan, asap rokok juga tidak kalah buruknya dari asap kendaraan karena mengandung unsur unsur senyawa kimia yang dapat menyebabkan penyakit.

Lingkungan menjadi permasalahan serius di Jakarta. Bahkan buruknya kualitas lingkungan menempatkan Jakarta sebagai kota dengan tingkat polusi udara terburuk ketiga di dunia setelah Meksiko dan Thailand. Indonesia menduduki urutan ketiga didunia. Salah satu kota di wilayah DKI Jakarta, yaitu Rawamangun, merupakan wilayah dengan penduduk sangat padat, jarak antar rumah yang satu dengan yang lain sangat berdekatan dengan tingkat kemiskinan yang cukup tinggi. Lingkungan tersebut dijadikan pemukiman warga masyarakat yang dijadikan daerah kost mahasiswa UNJ, di antaranya adalah yang berlokasi di sekitar kampus A, Universitas Negeri Jakarta RT 009/RW 05, Kelurahan Rawamangun Kecamatan Pulogadung Jakarta Timur. Banyaknya kendaraan bermotor di area ini, memungkinkan tinggi pula tingginya pencemaran yang terjadi di wilayah tersebut. Asumsi ini, tentunya berdasarkan beberapa literatur, di mana zat polutan pada lingkungan dikatakan beresiko tinggi terhadap kesehatan tubuh, jika telah melewati ambang batas tertentu. Artinya semakin banyak kendaraan bermotor semakin tinggi pula polusi yang dihasilkan, terutama senyawa timbal $(\mathrm{Pb})$. Tingginya kandungan timbal pada sisa pembakaran bahan bakar minyak itu, antara lain karena digunakannya $\mathrm{Pb}$ sebagai campuran demi meningkatkan perfoma mesin kendaraan. Hal ini terbukti bahwa hasil penelitian Badan Pengendalian Dampak Lingkungan Daerah (Bapedalda) DKI Jakarta menyimpulkan bahwa ibu-ibu di pinggiran kota memiliki ASI berkadar timbal 10-30 $\mu$ g per kilogram. Kadar ini jauh lebih tinggi dibandingkan dengan mereka yang tinggal di pedesaan, yakni hanya 1-2 $\mu \mathrm{g} / \mathrm{kg}$. Polutan timbal yang dihasilkan dari pembakaran bahan bakar minyak, dapat memicu gangguan kesehatan kaum perempuan dan balita.

Beberapa tahun lalu United Nations Environmental Programme (UNEP) juga menempatkan Jakarta sebagai kota terpolusi nomor tiga di dunia setelah Meksiko dan Bangkok. DKI Jakarta adalah salah satu kota dengan tingkat polusi paling tinggi di Indonesia. Hal ini dibuktikan dengan adanya kerusakan di berbagai aspek lingkungan, seperti air dan udara. Polusi udara, diakibatkan oleh melonjaknya volume kendaraan bermotor yang menyebabkan tingkat polusi udara di DKI Jakarta semakin meningkat. Sebagian besar kendaraan bermotor di kota-kota besar masih menggunakan bahan bakar fosil seperti Hidrogen $(\mathrm{H})$ dan Karbon monoksida(CO), karbon dioksida $(\mathrm{CO} 2)$ juga Nox. Selain menyebabkan infeksi saluran pernapasan (ISPA), cemaran asap knalpot itu juga mengancam kecerdasan anak. Penelitian PBB terbaru melaporkan, sebanyak 5500 anak meninggal setiap harinya akibat penyakit yang di sebabkan oleh 
air dan makanan yang tercemar zat polutan. Polutan juga telah memakan jutaan korban anak. Hasil penelitian WHO menambahkan 1-3 masalah kesehatan global disumbang dari efek polutan di lingkungan. Lebih dari 40 persen resiko ini menyerang anak usia di bawah 5 tahun.

Menurut dokter kesehatan masyarakat Departemen Kesehatan Lingkungan, Fakultas Kesehatan Masyarakat UI, DR.Dr. Rachmadi Purwana SKM, polutan yang kerap masuk ke tubuh anak yaitu Timbal, berasal dari proses pembakaran yang tidak sempurna pada bahan bakar kendaraan bermotor dan mesin-mesin pabrik, menyebar melalui asap sisa pembakaran yang kemudian terhirup manusia. Polutan tersebut, mempengaruhi kesehatan organ-organ tubuh anak dan berdampak pada proses tumbuh kembang anak. Logam berat itu selanjutnya dapat terakumulasi ke otak, menyebabkan pengerutan jaringan otak sehingga fungsi otak menurun, atau menghambat pembentukan darah, yang menyebabkan anemia. Di luar ancaman penurunan tingkat kecerdasan, udara yang tercemar logam berat dan zat-zat polutan juga dapat memicu bronchitis, pneumonia, asma serta gangguan fungsi paru.

Logam berat yang masuk kedalam tubuh manusia bereaksi dengan gugus "S" (sulfihidril) pada enzim. Enzim yang telah terkontaminasi oleh logam berat tersebut menjadi tidak aktif. Hal ini mengakibatkan metabolisme tubuh akan terganggu. Apabila metabolisme tubuh mengalami gangguan yang lebih lanjut dapat mengakibatkan kematian (Saeni, 2000). Logam berat dalam tubuh manusia biasanya terakumulasi pada beberapa organ tubuh seperti ginjal, hati, kuku, jaringan adiposa, dan rambut. Akumulasi kandungan logam berat dapat juga terjadi pada darah ataupun urin. Logam berat yang berada pada darah atau urin, biasanya tidak bertahan lama dan dapat segera dikeluarkan melalui siklus metabolism tubuh. Jumlah logam dalam rambut berkorelasi dengan jumlah logam yang diabsorpsi oleh tubuh. Oleh karena itu, rambut dapat dipakai sebagai biopsy material (Lawrance, 2001). Sementara itu, logam berat itu sendiri dapat mengganggu perkembangan kognitif pada anak-anak. Logam berisiko karena punya kecenderungan untuk menyerap lebih banyak zat-zat pada anak kecil daripada orang dewasa.

Proses masuknya polutan ini tak hanya melalui kontak langsung misalnya pernapasan, kulit, dan sebagainya, Namun juga meracuni bayi yang sedang dikandung. Pada fase kehamilan, bayi menyerap nutrisi dari si ibu. Termasuk semua komponen merkuri yang mengalir dalam darah ibu akan ikut ditransfer ke bayinya. Jika air raksa masuk ke dalam tubuh perempuan hamil, anak-anak yang dilahirkan akan mengalami cacat tubuh yang sifatnya tanpa kaki, tanpa tangan atau bentuk kepala tidak beraturan.

Penanganan penyakit akibat polutan memiliki sifat dilematis. Karena kemungkinan dipicu oleh penyebab lain. Untuk menentukan zat-zat berbahaya yang mencemari tubuh, perlu dilakukan penelitian lebih komprehensif melalui tes laboratorium kuku, rambut, darah, dan air seni. Untuk mengetahui tinggi rendahnya paparan logam berat, dilakukan pemeriksaan rambut. Sedangkan, pemeriksaan darah bertujuan untuk mengetahui kadar keracunan yang diakibatkan oleh timbal. Kemudian dilakukan pemeriksaan genetik. Sayangnya, di Indonesia pemeriksaan tersebut sulit diaplikasikan akibat tingginya biaya yang harus dikeluarkan. Perbedaan dampak polutan pada anak antara lain disebabkan oleh perbedaan system imun yang mampu menyaring polutan, sehingga tingkat kemudahan untuk menyerap polutan tidaklah sama. Di sinilah peran orang tua, ibu hamil dan calon ibu, yang mana perlu di bekali pengetahuan mengenai zat-zat polutan. Terutama mewaspadai kondisi lingkungan di 
sekitar rumah dengan pengetahuan yang memadai. Hal yang paling penting lagi adalah peran kader kesehatan PKK setempat dalam memberikan penyuluhan terkait dengan logam berat dan dampaknya.

\section{METODE PELAKSANAAN}

Kegiatan yang akan dilakukan meliputi penyuluhan, pemberian informasi dampak pencemaran logam berat terhadap kesehatan dan teknologi peneriksaan sederhana kandungan logam berat di air sekitar tempat tinggal dan ditubuh.

Kegiatan pengabdian masyarakat ini dilakukan di lingkungan warga Kayu Jati RW 05 Kelurahan Rawamangun Kecamatan Pulogadung Jakarta Timur dengan kelompok sasaran adalah ibu-ibu hamil, calon ibu dan remaja putri. Kegiatan ini dilakukan berupa penyuluhan dan sosialisasi terhadap hasil penelitian dengan materi yang terkait dengan peneliti. Metode pelaksanaan yang akan dilakukan dalam kegiatan pelaksanaan ini dilakukan dengan tahapan sebagai berikut:

1. Pendataan sampel secara acak diambil dari rumah warga RW 09 sebanyak 25 dari ibu ibu, serta calaon ibu dan remaja putri. Instrumen berupa kuisioner yang harus diisi oleh ibu rumah tangga dan remaja putri peserta kegiatan.

2. Deteksi senyawa toksik dengan mengambil sampel rambut dari ibu dan calon ibu. Pemeriksaan di laboratorium untuk mendeteksi adanya logam berat melalui penentuan kadar $\mathrm{Pb}-\mathrm{Cu}$ dengan metode AAS.

\section{Prosedur Dekstruksi Sampel}

Sampel rambut di destruksi sampai homogen, dimasukkan kedalam cawan petri dan ditimbang sebanyak 5 gram dengan timbangan digital. Lalu ditambahkan adalah HNO3 $5 \mathrm{ml}$ dan $\mathrm{H}_{2} \mathrm{SO}_{4} 5 \mathrm{ml}$ dan dibiarkan di lemari asam selama 24 jam, kemudian dipanaskan diatas mantel pemanas pada suhu sedang yaitu $60^{\circ} \mathrm{C}$ selam 30 menit, kemudian dilanjutkan pada suhu tinggi yaitu $120^{\circ} \mathrm{C}-150^{\circ} \mathrm{C}$ sampai terbentuk endapan hitam. setelah itu didinginkan, setelah dingin ditambahkan $10 \mathrm{ml}$ asam nitrat $10 \%$ dan di kocok sampai endapan hitam larut. Setelah itu ditambahkan $\mathrm{H} 2 \mathrm{O} 2$ sebanyak $3 \mathrm{ml}$ dan di kocok, kemudian di panaskan lagi lebih kurang 15 menit. Setelah dingin, larutan hasil destruksi disaring dengan kertas saring whatmen No. 42, dan dimasukkan dalam labu ukur $50 \mathrm{~mL}$ dan diencerkan sampai tanda batas. Sebanyak $200 \mathrm{~mL}$ sampel siap untuk dianalisis logam berat $\mathrm{Pb}$ dan $\mathrm{Cu}$ dengan metoda AAS (SNI, 2005).

\section{HASIL DAN PEMBAHASAN}

Logam merupakan unsur penting yang dibutuhkan setiap makhluk hidup. Logam berat dibedakan dalam dua kategori, yaitu logam essensial dan logam non essensial. Logam non esensial, termasuk elemen mikro merupakan kelompok logam berat yang tidak mempunyai fungsi sama sekali dalam tubuh. Logam tersebut bahkan sangat berbahaya dan dapat menyebabkan keracunan (toksik) pada manusia yaitu timbal $(\mathrm{Pb})$ dan $\mathrm{Cu}$ (Agustina, 2010). Logam berat umumnya bersifat racun terhadap makhluk hidup, walaupun beberapa diantaranya diperlukan dalam jumlah kecil. Senyawa tersebut dapat terdistribusi ke bagian tubuh manusia melalui udara, makanan, maupun air yang terkontaminasi, dan sebagian akan terakumulasikan. Jika keadaan ini 


\section{Yulia Irnidayanti, Reni Indrayanti}

berlangsung terus menerus, dalam jangka waktu lama dapat mencapai jumlah yang membahayakan kesehatan manusia. Timbal atau Plumbum adalah metal kehitaman, dahulu di gunakan sebagai konstituen dalam cat, baterai, dan saat ini banyak digunakan dalam bensin. Tetra Ethyl Lead atau TEL sengaja ditambahkan kedalam bensin untuk meningkatkan nilai oktan. Di atmosfer di kota-kota besar, timbal dijumpai dalam jumlah besar dan biasanya berasal dari gas buangan kendaranan bermotor. Pertambahan jumlah kendaraan bermotor sekarang yang sangat pesat memberikan dampak negatif. Kendaraan bermotor merupakan penyumbang utama dari seluruh emisi racun di udara. Satu diantaranya emisi racun di udara adalah logam timbal. Polusi udara ini dapat menyebabkan penyakit jika terakumulasi terlalu lama dalam darah manusia (Ardyanto, 2005).

Pada Rambut gugus sulfhidril dan disulfida dalam rambut mampu mengikat unsur runut yang masuk ke dalam tubuh dan terikat di dalam rambut. Senyawa sulfida mudah terikat oleh unsur runut, maka bila unsur runut masuk ke dalam tubuh, unsur runut tersebut akan terikat oleh senyawa sulfida dalam rambut (Petrucci, 1982). Timbal terakumulasi di lingkungan, tidak dapat terurai secara biologis dan toksisitasnya tidak berubah sepanjang waktu. Unsur tersebut bila terhirup atau tertelan oleh manusia akan beredar mengikuti aliran darah, dan diserap oleh ginjal dan otak, atau terakumulasi di tulang dan gigi. Keracunan $\mathrm{Pb}$ secara kronis berjalan lambat dan paparan dengan dosis rendah dapat menyebabkan gangguan pada sistem saraf pusat, gangguan menstruasi, mengganggu sistem reproduksi serta aborsi spontan pada wanita.

Tembaga $(\mathrm{Cu})$, yang masuk kedalam tatanan lingkungan perairan dapat berasal dari peristiwa-peristiwa alamiah dan sebagai efek samping dari aktivitas yang dilakukan oleh manusia. Selain itu, akibat yang ditimbulkan oleh tembaga dalam kadar tinggi adalah kerusakan pada ginjal, hati, muntaber, pusing kepala, anemia, dan dapat meninggal. Sedangkan pada dosis yang rendah menimbulkan rasa kesat, warna, korosi pada pipa, sambungan dan peralatan dapur

Pada pemeriksaan terhadap kadar logam $\mathrm{Pb}$ (nonessensial dan logam $\mathrm{Cu}$ (essensial) pada warga RW009, menunjukkan bahwa tidak ditemukan logam barat $\mathrm{Pb}$ yang terkandung dalam tubuh warga, juga pada air yang digunakan setiap hari oleh warga (tabel 1). Tidak ditemukannya kandungan $\mathrm{Pb}$ pada sampel rambut, kemungkinaan disebabkan sebagian besar sampel rambut, berasal dari warga yang memakai jilbab. Oleh karena itu saat pemeriksaan tidak dijumpai adanya logam $\mathrm{Pb}$, tetapi dijumpai logam essensial $\mathrm{Cu}$ yang memang dibutuhkan oleh tubuh. Logam $\mathrm{Cu}$ kemungkinan diperoleh dari bahan makanan yang mereka konsumsi. Pencemaran timbal di udara dapat disebabkan oleh asap yang berasal dari knalpot kendaraan. Baku mutu udara ambien untuk timbal berdasarkan PP RI No. 41 Tahun 1999 yaitu sebesar 2,0 $\mathrm{g} / \mathrm{Nm}^{3}$. Berdasarkan hal tersebut, diduga bahwa tidak ditemukannya timbal pada rambut warga, tetapi mungkin terdapat dalam darah.

Baku mutu timbal di perairan berdasarkan PP No. 20 tahun 1990 adalah 0,1 $\mathrm{mg} / \mathrm{l}$ dan Rata-rata timbal yang terdapat di dalam tanah adalah sebesar $5-25 \mathrm{mg} / \mathrm{kg}$ (Widowati et.al, 2008). Rekomendasi dari WHO, logam berat $\mathrm{Pb}$ dapat ditoleransi dalam seminggu dengan takaran $50 \mathrm{mg} / \mathrm{kg}$ berat badan untuk dewasa dan $25 \mathrm{mg} / \mathrm{kg}$ berat badan untuk bayi dan anak-anak. Mobilitas timbal di tanah dan tumbuhan cenderung lambat dengan kadar normalnya pada tumbuhan berkisar 0,5-3 ppm (Widyaningrum, 2007). Berdasarkan data literatur bahwa kemungkinan sumber timbal yang menjadi pencemaran adalah berasal dari polusi udara kendaraan bermotor. 
Meskipun data kandungan $\mathrm{Pb}$ dalam rambut tidak ditemui, tetapi dugaan sementara bahwa kandungan $\mathrm{Pb}$ mungkin ditemukan di dalam darah. Dugaan ini berdasarkan asusmsi bahwa konsentrasi $\mathrm{Pb}$ di dalam darah merupakan indikator yang lebih baik dibandingkan dengan konsentrasi $\mathrm{Pb}$ di dalam urin dan rambut. Sumber timbal lainnya diduga berasal darai kosmetik.

Logam berat yang terkandung dalam kosmetik umumnya merupakan zat pengotor (impuritis) pada bahan dasar pembuatan kosmetik. Logam berat seperti timbal $(\mathrm{Pb})$ dalam kosmetik berperan sebagai penstabil dan pelembut tekstur (Junger dan Greeven, 2009). Beberapa kosmetik, seperti lipstik ditemukan mengandung timbal (Utomo dalam Sihite, 2015). Pemanfaatan timbal pada lipstik di bibir supaya tahan dari pengoksidasian udara (oxidation) dan tahan air (waterproof). Pemanfaatan ini sesuai dengan sifat timbal, yatu memiliki sifat sulit larut dalam air dingin dan air panas (Palar, 2008).

Tabel 1. Hasil pemeriksaan logam $\mathrm{Pb}$ dan $\mathrm{Cu}$ pada rambut warga kelurahan Rawamangun RW009

\begin{tabular}{|c|c|c|c|}
\hline No & Sampel & Kadar Pb (ppm) & Kadar $\mathrm{Cu}(\mathrm{ppm})$ \\
\hline 1 & 1 & $-11,9284$ & 0,0527 \\
\hline 2 & 2 & $-11,9360$ & $-0,0236$ \\
\hline 3 & 3 & $-11,9360$ & $-0,0267$ \\
\hline 4 & 4 & $-11,9208$ & $-0,0347$ \\
\hline 5 & 5 & $-11,9093$ & 0,0596 \\
\hline 6 & 6 & $-11,9170$ & 0,0819 \\
\hline 7 & 7 & $-11,9093$ & 0,0496 \\
\hline 8 & 8 & $-11,9055$ & 0,0329 \\
\hline 9 & 9 & $-11,9055$ & 0,0515 \\
\hline 10 & 10 & $-11,8941$ & 0,1532 \\
\hline 11 & 11 & $-11,9055$ & 0,0912 \\
\hline 12 & 12 & $-11,3910$ & 0,1787 \\
\hline 13 & 13 & $-11,9055$ & 0,3021 \\
\hline 14 & 14 & $-11,9093$ & 0,1669 \\
\hline 15 & 15 & $-11,8750$ & 0,0261 \\
\hline 16 & 16 & $-11,8903$ & $-0,0136$ \\
\hline 17 & 17 & $-11,8598$ & 0,0292 \\
\hline 18 & 18 & $-11,8788$ & 0,0509 \\
\hline 19 & 19 & $-11,8674$ & $-0,0292$ \\
\hline 20 & 20 & $-11,8674$ & 0,0099 \\
\hline 21 & 21 & $-11,8788$ & $-0,0769$ \\
\hline 22 & 22 & $-11,8598$ & $-0,0788$ \\
\hline 23 & 23 & $-11,8407$ & $-0,0788$ \\
\hline
\end{tabular}

Hasil pemeriksaan terhadap gula darah dan asam urat tertera pada tabel 2 dibawah ini. Kadar gula darah yang tinggi, ditemukan pada tiga warga di kelurahan 
Yulia Irnidayanti, Reni Indrayanti

Rawamangun, dengan usia produktif 32, 43 dan 58 tahun. Dari hasil wawancara penderita diabetes, bahwa mereka baru mengetahui menderita diabetes. Meskipun penderita diabetes tidak dalam masa kehamilan, namun mereka harus tetap waspada dengan kadar gula yang tinggi. Wanita yang memiliki tingkat kadar gula darah (glukosa) yang tinggi sepanjang masa kehamilannya, akan berpengaruh pada bayi yang dilahirkan. Bayi yang lahir dari ibu dengan penyakit diabetes sering lahir dengan ukuran lebih besar dibandingkan bayi lainnya. Organ dalam seperti liver, kelenjar adrenal, dan jantung cenderung membesar. Proses kelahiran biasanya sulit jika ukuran si bayi besar. Hal ini dapat meningkatkan risiko cedera pleksus brakialis dan trauma lainnya selama melahirkan.Biasanya setelah lahir, kadar gula bayi akan menurun, namun perlu pengawasan terhadap kadar gula darah si bayi dalam waktu 12-24 jam pertama setelah kelahiran. Jika si ibu sudah menderita diabetes sebelum masa kehamilannya, maka bayinya memiliki peningkatan risiko cacat saat lahir jika penyakit diabetes si Ibu tidak dikendalikan dengan baik. Hasil pemeriksaan asam urat pada warga Rawamangun, menunjukkan bahwa kondisi asam urat dalam kategori normal, kecuali satu warga usia lansia dengan kadar asam urat yang tinggi. Rata-rata kadar asam urat normal pada perempuan berkisar 2,4-6,0 miligram per desiliter $(\mathrm{mg} / \mathrm{dL})$ dan pada laki-laki: 3,4-7,0 mg/dL. Bila dalam kondisi tidak hamil, tidak terlalu berbahaya, namun asam urat pada masa kehamilan dapat mengakibatkan resiko hipertensi gestasional dan diabetes saat hamil. Pada dasarnya, kadar normal asam urat pada ibu hamil sebesar 3.6-6, jika melebihi sedikit batas tersebut maka ibu telah memasuki tahap awal gejala asam urat.

Tabel 2. Hasil pemeriksaan gula darah dan asam urat warga kelurahan Rawamangun RW009

\begin{tabular}{clccc}
\hline No & Nama & Usia (thn) & Kadar Gula darah & $\begin{array}{l}\text { Kadar } \\
\text { urat }\end{array}$ \\
\hline 1 & Lia & 30 & 78 & 6.0 \\
\hline 2 & Dwi & 46 & 83 & 5.9 \\
\hline 3 & Putu & 57 & 143 & 4.5 \\
\hline 4 & iyan & 53 & 143 & 5.9 \\
\hline 5 & Nurjalina & 46 & 129 & 7.0 \\
\hline 6 & Suharyati & 49 & 110 & 4.9 \\
\hline 7 & Ayu & 48 & 89 & 5.4 \\
\hline 8 & Ana & 47 & 110 & 5.9 \\
\hline 9 & Yuni & 29 & 94 & 4.4 \\
\hline 10 & Yanti & 40 & 104 & 5.5 \\
\hline 11 & Ena Nurjanah & 46 & 119 & 6.0 \\
\hline 12 & Ria & 32 & 214 & 5.7 \\
\hline 13 & Saroh & 43 & 132 & 6.4 \\
\hline 14 & Rapina & 71 & 171 & 11.7 \\
\hline 15 & Maryati & 58 & 105 & 2.5 \\
\hline 16 & Hermiliana & 32 & 98 & 3.2 \\
\hline 17 & Maemunah & 40 & 135 & 4.6 \\
\hline 18 & Marlina & 37 & 112 & 5.2
\end{tabular}


BAKTIMAS

Vol. 2, No. 1,

eISSN 2685-113x

Jurnal Pengabdian pada Masyarakat

Maret 2020

pISSN 2685-0303

\begin{tabular}{llccc}
20 & Endang & 61 & 139 & 5.2 \\
\hline 21 & Fatmawati & 34 & 79 & 5.8 \\
\hline 22 & Meti & 37 & 118 & 3.3 \\
\hline 23 & Siti Aminah & 43 & 83 & 3.2 \\
\hline 24 & Hernawati & 40 & 135 & 4.6 \\
\hline 25 & Iis & 42 & 103 & 5.6 \\
\hline
\end{tabular}

Foto kegiatan P2M
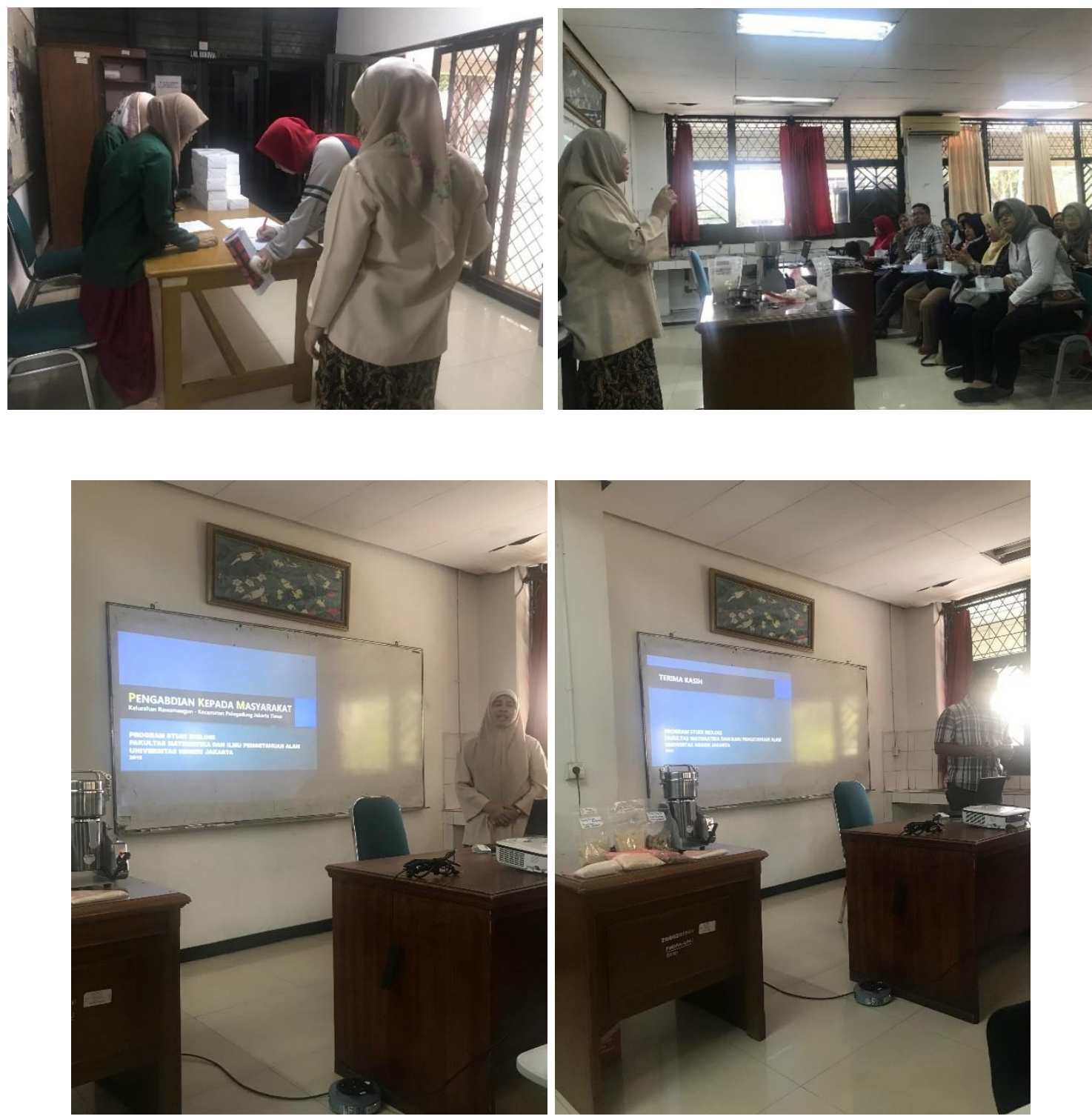
Yulia Irnidayanti, Reni Indrayanti

\section{Kesimpulan}

\section{PENUTUP}

Pengabdian masyarakat dengan topik "Peningkatan Pengetahuan Ibu Hamil Dan Calon Ibu Tentang Polutan Logam Berat Dalam Rangka Pencegahan Cacat Lahir Di Rawamangun, Jakarta Timur" telah terlaksana dengan baik. Sambutan masyarakat di Rawamngun sangat baik dan mengharapkan kegiatan serupa dilaksanakan secara rutin. Hasil analisis menunjukkan tidak ditemukannya logam berat $\mathrm{Pb}$ pada rambut warga, dan beberapa ditemukan logam $\mathrm{Cu}$ pada beberapa warga.

Saran

Perlu analisis logam $\mathrm{Pb}$ dan $\mathrm{Cd}$ pada sampel darah warga, agar data lebih akurat.

\section{DAFTAR PUSTAKA}

Ardyanto D. 2005. Deteksi Pencemaran Timah Hitam (Pb) dalam Darah Masyarakat yang Terpajan Timbal (Plumbum). Kesehatan Lingkungan, 2:67-76.

Agustina, Titin. 2010. Kontaminasi Logam Berat Pada Makanan Dan Dampaknya Pada Kesehatan. TEKNUBUGA Volume 2 No 2. TJP Fakultas Teknik UNNES

Amad.J.S.,Eaton. 2005. Study on the Removal of Iron and Manganese in Groundwater by Carlson et al. 1997. Psycology, the Science of Behaviour. Boston: Allyn \& Bacon.

Prinsip-prinsip Masalah Pencemaran Lingkungan. Surabaya: Ghalia Indonesia.

Alsagaff,H,1993. Nilai Normal Faal Paru Orang Indonesia Pada Usia Sekolah Dan Pekerja

Departemen Kesehatan RI. 2000. Modul Pelatihan Bimbingan dan Penyuluhan Kesehatan Reproduksi Remaja bagi Petugas Kesehatan. Jakarta: Direktorat Kesehatan Keluarga Dirjen Bina Kesehatan Masyarakat

Dewasa Berdasarkan Rekomendasi American Thoracic Society (ATS). Airlangga University Press, Surabaya.

Junger, Alenjandro MD., Greeven A. 2009. CLEAN: Program Revolusioner Mengembalikan Kemampuan Alami Tubuh untuk Menyembuhkan Diri. Bandung: PT. Mizan Pustaka.

Lawrence D. and Wilson, M. D. (2001). Tissue Mineral Analysis, Medical Doctor About Hair Analysis 10(4).

Palar, H. 2008. Pencemaran dan Toksikologi Logam Berat. Rineka Cipta. Jakarta

Petrucci RH. 1982. General Chemistry. McMillan Publ, Co, Inc, New York.

Widowati., Sastiono., Jusuf., 2008. Efek Toksik Logam : Pencegahan dan Penanggulangan Pencemaran. Andi Offset. Yogyakarta.

Saeni, M.S. 1995. The correlation between the concentraion of heavy metals $(\mathrm{Pb}, \mathrm{Cu}$ and $\mathrm{Hg}$ ) in the environment and in human hair. Bulletin Kimia 9:63-70

Sihite, H. M., 2015. Analisis Kandungan Timbal pada Lipstik Impor dan dalam Negeri Serta Tingkat Pengetahuan Konsumen dan Pedagang Terhadap Lipstik yang Beredar di Pasar Petisah Kota Medan Tahun 2015. Skripsi Fakultas Kesehatan Masyarakat USU. Medan.

Sukirno\&Murniasih, S. 2009. Analisis Unsur Fe, Ca, Ti, Ba, Ce, $\mathrm{Zr}$ dan $\mathrm{La}$ dalam Sedimen 
Sumardi. 2002. Validasi Metode Pengujian. Jakarta: Pusat Standardisasi dan Akreditasi Sekretariat Jendral Depertemen Pertanian.

Standar Nasional Indonesia 189-7119.4-2005. 2005. Cara Uji Kadar Timbal $(\mathrm{Pb})$ dengan Metode Destruksi Basah Menggunakan Spektrofotometer Serapan Atom.

Subagiada, Kadek. 2011. Penentuan Kadar Timbal (Pb) dengan Bioindikator Rambut pada Pekerja SPBU Di kota Samarinda. Skripsi. Jurusan Fisika FMIPA, Universitas Mulawarman.

Underwood, A.L. dan Day R.A. 2001.Analisa Kimia Kualitatif Edisi Keenam. Jakarta:Erlangga.

Wegscheider. 1996. Validation of Analytical Methods, in Accreditation and Quality Assurance in Analytical Chemistry. Berlin: Springer Verlag.

Widowati. H. 2011. Pengaruh Logam Berat $\mathrm{Cd}, \mathrm{Pb}$ Terhadap Perubahan Warna Batang dan Daun Sayuran. Jurnal Sains. Vol. 1, No. 4.

Widiningrum, Miskiyah dan Suismono,2007, Jurnal pertanian. AhayaKontaminasi Logam Berat DalamSayuran dan Alternatif PencegahanCemarannya, Vol.3, Balai BesarPenelitian dan Pengembangan PascaPanen Pertanian, Jakarta.

https://www.inews.id/news/megapolitan/rakyat-bicara-jakarta-darurat-limbah/61390

file://C:/Users/user/Downloads/infodatin\%20kelainan\%20bawaan.pdf 